\title{
RECOVERY OF MERCURY OF AMALGAMS IN DIGGING GOLD - RETORTA RHYP
}

\author{
RECUPERAÇÃO DE MERCÚRIO DE AMÁLGAMAS DE OURO EM GARIMPO - \\ RETORTA RHYP
}

\author{
Raphael HYPOLITO, Ernesto Massayoshi SUMI \\ Instituto de Geociências - Universidade de São Paulo. End. Rua do Lago, 562, Cidade Universitária. \\ Emails: rhypo@igc.usp.br, ernest.sumi@usp.br

Introduction
Mercury
Objectives
Digging Gold
Conclusions
References

\begin{abstract}
Among the heavy metal ions, the mercury cations are especially prominent because they are not biodegradable and because of their capacity to accumulate in organisms along the food chain, magnifying themselves. Once absorbed the mercury ions cause, among others, neurological damage, cerebral palsy, tremors, muscle fibrillation, pulmonary irritation, renal impairment, etc. and even death. Small-scale, homemade gold extraction is usually carried out in diggings from metal mercury in the form of amalgams. This technique is one of the major sources of mercury pollution in the environment and, therefore, it is always necessary to use instruments that minimize its effects. This was the stimulus for the development of the Retorta RHYP that was developed in the Laboratory of Chemistry, the Institute of Geosciences of the University of São Paulo, presented in this paper. In addition to being extremely low cost, easy to assemble, it recovers mercury from amalgam of gold to values close to $100 \%$. It is a retort that still has the advantage of being easy to carry and that does not require refrigeration. Despite little dissemination, The Retorta RHYP has been used in many countries in Africa, The Philippines and also in some South American countries, requiring further dissemination through work such as this one being presented.
\end{abstract}

Keywords: retort, gold-digging, mercury, mercury amalgam, contamination.

RESUMO - Dentre os íons de metais pesados, os cátions de mercúrio se sobressaem especialmente por não serem biodegradáveis e pela sua capacidade em se acumular nos organismos ao longo da cadeia alimentar, magnificando-se. Uma vez absorvidos os íons de mercúrio causam, entre outros, danos neurológicos, paralisia cerebral, tremores, fibrilação muscular, irritação pulmonar, comprometimento renal, etc. e até a morte. A extração de ouro em pequena escala, de modo caseiro, normalmente é efetuada em garimpos a partir de mercúrio metálico sob a forma de amálgamas. Essa técnica constitui-se em uma das maiores fontes de poluição por mercúrio no meio ambiente e, portanto, é sempre necessário o uso de instrumentos que minimizem seus efeitos. Este foi o estímulo para que fosse desenvolvido no Laboratório de Química o Instituto de Geociências da Universidade de São Paulo, a Retorta RHYP, apresentada neste trabalho. Ela, além de baixíssimo custo, de fácil montagem, recupera o mercúrio de amálgama de ouro a valores próximos de $100 \%$. É uma retorta que apresenta ainda a vantagem de ser de fácil transporte de não necessitar de refrigeração. A Retorta RHYP, apesar de pouca divulgação tem sido utilizada em muitos países da África, Filipinas e também em alguns países da América do Sul necessitando ainda de maior divulgação através de trabalhos como este que ora está sendo apresentado.

PAlavras-chave: Retorta, Extração de ouro, Mercúrio, Amálgama de mercúrio, Contaminação.

\section{INTRODUCTION}

\section{Mercury}

Mercury is a silvery, odorless metal that, at room temperature, is in the liquid state. It is obtained mainly by the ustulation of cinnabar (HgS) at $500{ }^{\circ} \mathrm{C}-600{ }^{\circ} \mathrm{C}$ in the presence of oxygen:

$$
\mathrm{HgS}(\mathrm{s})+\mathrm{O}_{2}(\mathrm{~g})=\mathrm{Hg}(\mathrm{s})+\mathrm{SO}_{2}(\mathrm{~g})
$$

It is stable in the atmosphere, soil and water and can be presented as elemental mercury, as mono and bivalent cations and covalently bound to organic radicals (organomercurial compounds).

In the gaseous state it exhibits monoatomic particles which in water are in equilibrium between the forms: elemental ( $\mathrm{Hg})$, dimer
$\left(\mathrm{Hg}_{2}{ }^{2+}\right)$ and bivalent cationic $\left(\mathrm{Hg}^{2+}\right)$.

$$
\mathrm{Hg}=\mathrm{Hg}_{2}{ }^{2+}=\mathrm{Hg}^{2+}
$$

The most stable form of mercury is bivalent which, by microbiological action, can become methylmercury $\left(\mathrm{CH}_{3}-\mathrm{Hg}^{+}\right)$, a bioaccumulative ion that is the most toxic among organic forms (Hansen \& Danscher, 1997; Stumm \& Morgan, 1996; Baird, 2004).

It is a teratogenic chemical agent and, once absorbed by the body, causes severe neurological damage such as cerebral palsy leading to death (Pinheiro et al., 2004).

Organomercurial compounds, even at low concentrations, are much more toxic than their other forms. When mercury (II) is bound to 
sulfhydryl groups existing in the proteins of living beings, it inactivates them. In this way, it is clear that mercury, in any of its three forms, gaseous, cationic or organic, is a chemical component of very high hazard, contributing significantly to the pollution of the environment.

\section{OBJECTIVE}

Although the use of Retorta RHYP has already been reasonably disclosed in the scientific environment and even among the digging gold miners, because of its effectiveness, the low cost and how easy it is to assemble, its usage must be even more widespread. The objective of this work is to do advocate for the usage of this method.

\section{Digging Gold}

Small-scale, home-made digging gold is usually carried out in mines from metal mercury in the form of amalgams (Melamed \& Villas Bôas, 2002, Bezerra \& Veríssimo, 1998, Lacerda et al. 1990, Melamed, \& Villas Bôas, 2002. Pfeifer, 1991, Rimoli, 1988). This use constitutes one of the major sources of mercury pollution in the environment causing risks to the miners, to the populations that live in its surroundings and to all the flora and fauna of the region.

The extraction of gold with metallic mercury is usually carried out on land and on beds of water course. In the first case, on steep terrain, on slopes (basses) hydraulic dives are applied with strong jets of water and the displaced materials are destined to the separation of the gold.

In the rivers the sediments are dredged using hoses (suckers) operated almost always by divers.

In the process of digging gold, to separate the gold from the extracted mud, an equipment gold hog is also used (Melamed \& Villas Bôas, 2002). It is a carpeted slope containing a riffled trough (Canadian Tip) in which amalgam, unreacted mercury and sediments run off with water. The amalgam as well as the surplus mercury are separated. The process causes large losses of mercury that is partly left on the surface being infiltrated into the soil and part is transported through the waters.

The gold extraction, that is to say, on a small scale, is carried out by miners who work in the deposits of sediments in streams, on its margins, where they find nuggets and/or small particles of gold.

In those cases, the gold is separated using metal or wooden troughs shaped like a chinese hat (Figure 1a) in which the gold digger introduces little more than his half with water and soil/sediment in mixture with mercury. The pan is maintained with water and stirred continuously with circular motions until the clayey and coarse fractions (gravel) can be separated and discarded (Figure 1b).

The gold, the thinner portion of the sediment, as well as the mercury deposit in the center of the pan. If the material contains gold nuggets (picks or grains) they are collected manually and if the gold is found in fine particles (particulate) it is amalgamated within the batter itself and separated.

Usually the residual mercury that does not combine with the gold is left in the place or even discarded in the beds of the rivers.

Then, in small bricks of metal, the amalgamated gold is separated from the mercury by heating with a torch (Figure 2) releasing large quantities of mercury gas to the environment.
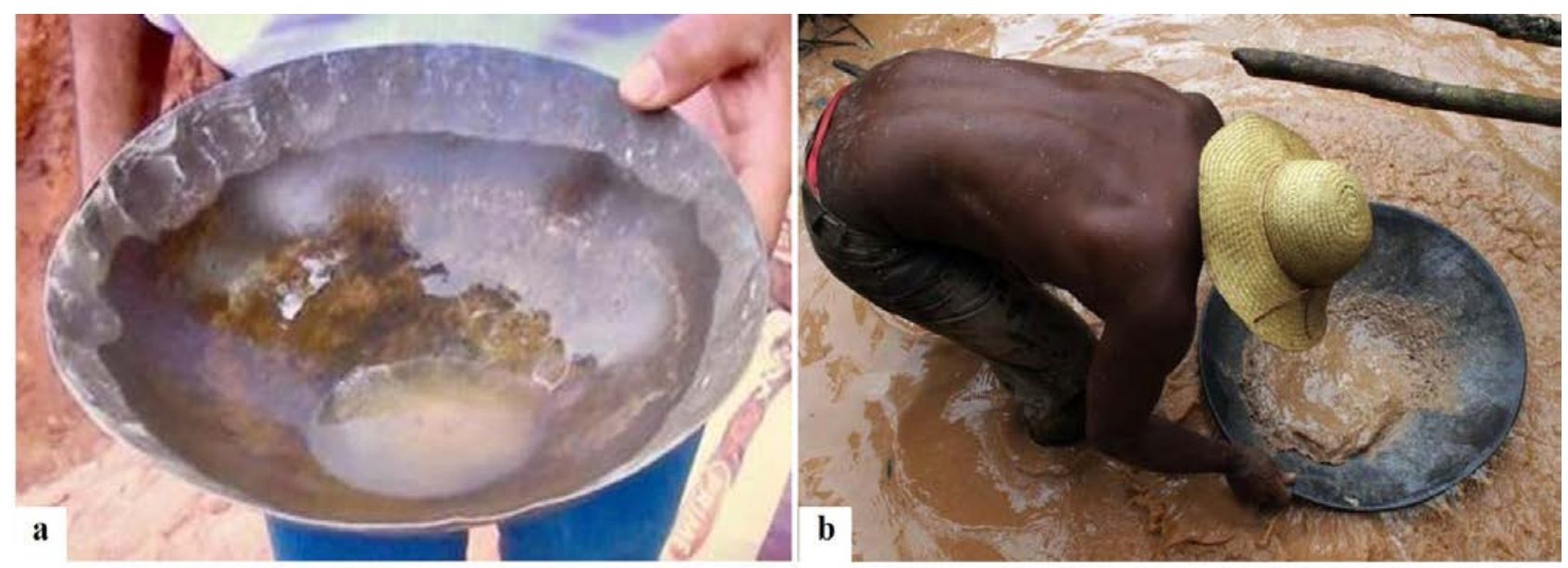

Figure 1 - Pan (a) and gold prospector with pan (b). 


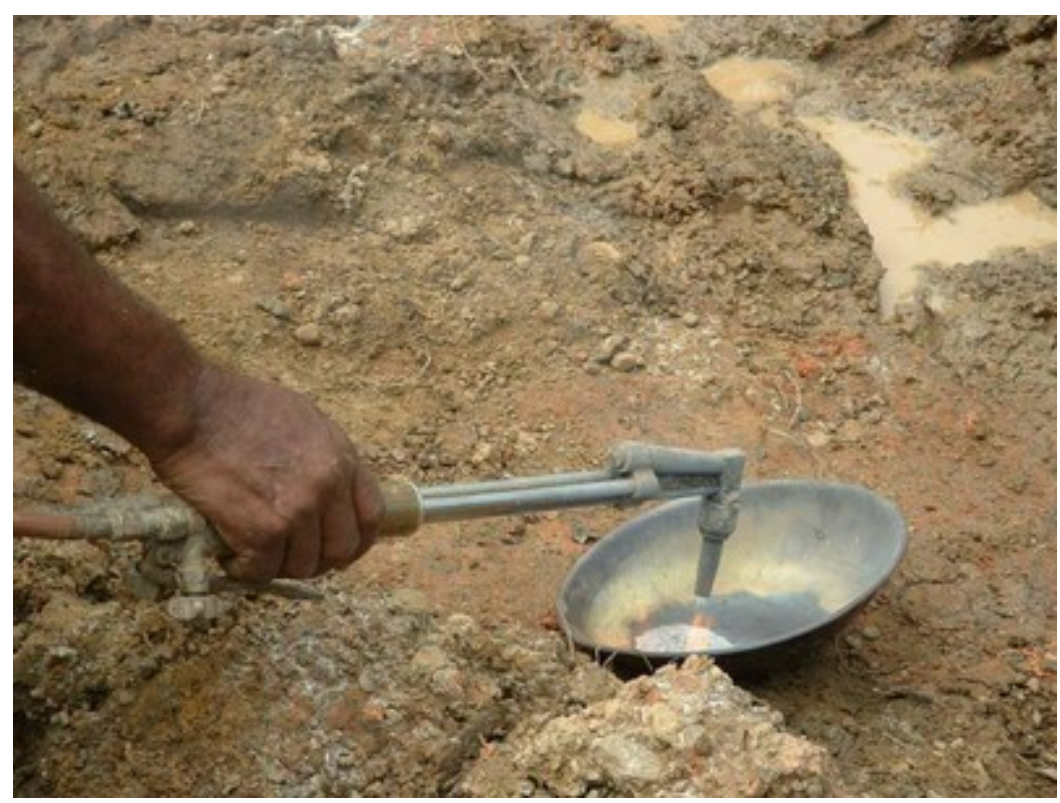

Figure 2 - Burning the amalgam to remove mercury with gold separation.

Reported ratio mercury/gold in amalgamation varies from author to author as it can be seen from table 1.

Table 1 - Amount of mercury/gold used in digging gold to the production of gold

\begin{tabular}{c|c|l}
\hline Hg (kg) & Au (kg) & \multicolumn{1}{|c}{ References } \\
\hline $\mathbf{1 , 7}$ & 1 & Melamed \& Villas Bôas (2002) \\
\hline $\mathbf{1 , 3}$ & 1 & Pfeifer et al., (1991) \\
\hline $\mathbf{1 , 4}$ & 1 & Pinheiro et al., (2000) \\
\hline $\mathbf{1 , 9}$ & 1 & Rimoli (1988) \\
\hline
\end{tabular}

For the Association to Combat Pollutants (ACPO, 2017) the $\mathrm{Hg} / \mathrm{Au}$ ratio is approximately 2:1. It is clear, therefore, that in the separation of the mercury from the amalgam of gold, a great quantity of the metal is spread in the surroundings of the gold digging area, in its gas form, aspirated by the miners that perform this task without protection.

In these operations the amalgam mercury is not totally eliminated and is nevertheless destined for the Gold Buyer Houses that make the gold in the chapels warm for the total elimination of the mercury and only then the pure metal is weighed for purchase.

These Houses are located in the urban perimeters of the cities and eliminate the toxic vapors around them at great distances.

In Boa Vista, the capital of the State of Roraima, in the Northern Region of Brazil, the authors of this study reported, among other diseases, births of children with anencephaly (total or partial absence of encephalon).

There are several types of retorts for the separation of gold into goldmine amalgams
(Trivelato, 2009). They are commercially available, all of them at high prices, which makes them impractical and usually inaccessible to mines. Usually they need the presence of piped water in the vicinity of the gold digging area necessary to cool the condenser of gas cylinder with support for heating the amalgam, which is difficult to transport, besides the exorbitant prices of these equipment's.

In search of a device that would allow the distillation of the mercury with high yield that would be, at the same time, cheap, feasible to the miners and that would still facilitate the transport of the equipment to the field the Retorta RHYP was developed in the Chemistry Laboratories of the Institute of Geoscience of the University of São Paulo (Hypolito \& Andrade, 1990; Hypolito et al., 1998).

The Retort consists basically of a Heating Chamber (1) and Condensation Rod (5), both of which are sized to the amount of metal to be recovered. The Heating Chamber comprises a plug (2) connected to an elbow (4) through a double nipple (3) (Figure 3). It is a device that can be easily assembled with inexpensive parts, around \$10, purchased from Building Materials Homes.

For the assembly of the Retort, one piece is recommended for the rod with a 20 inch length and a $1 / 4$ inch diameter. It should be folded at a distance of 4 inches from the elbow forming a smooth curve with angle of $60^{\circ}-70^{\circ}$. It may be an iron tube, such as an electric iron conduit.

However, if the parts are galvanized it is necessary, before assembly, that they are heated to high temperatures to eliminate the zinc layer they 
contain, since a reaction between $\mathrm{Hg} / \mathrm{Zn}$ may occur. Then the parts must be washed with water, tightly connected to each other by screwing them.

(1) heating chamber
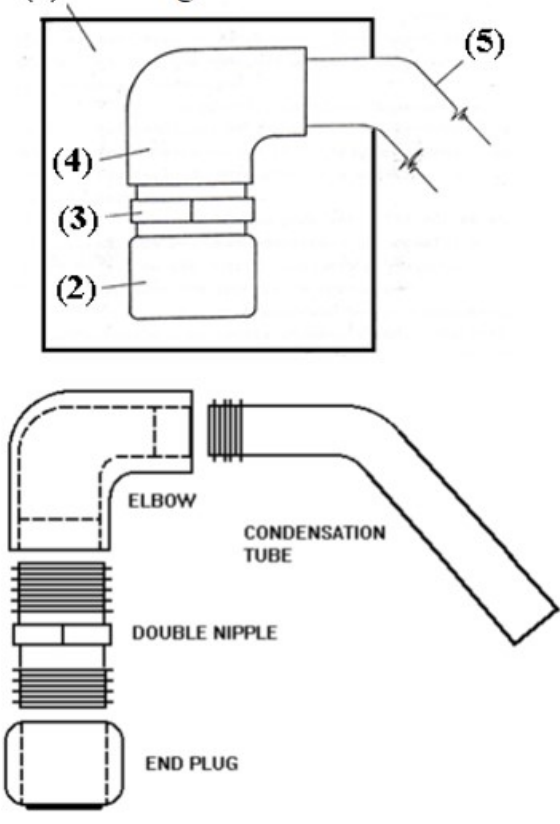

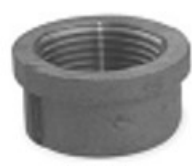

(2)

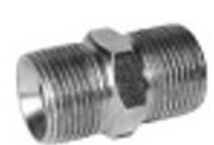

(3)

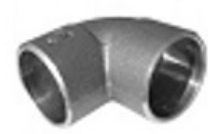

(4)

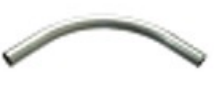

(5)

Figure 3 - Schematic, photo of Retorta RHYP and its component parts.

When the separation of mercury is not carried out in a field, for example, in Golden Buying Houses, the Heating Chamber may consist of electrical systems. However, in the field the heating of the chamber can be carried out in a wood or charcoal fire and even in wood stoves in homes.

In the laboratory the temperature variation of the rod was measured with thermoelectric torque and it was verified that the condensation of the mercury occurs already in the first centimeters of the rod, thus dispensing with the use of a refrigerator.

When heating the retort the cooling rod must be isolated from the source of heat and have its end dipped in a vial of water that must be removed as soon as the mercury drip stops, preventing water from flowing back into the chamber.

The calculated yield $\eta\left(\eta=\mathrm{mHg}_{\text {(extracted) }} /\right.$ $\mathrm{mHg}_{\text {(initial) }} \mathrm{x}$ 100) after a large number of experiments reached values close to $100 \%$.

Researcher Professor Marcelo Mariz da Veiga of the University of British Columbia
(UBC, Canada), who has greatly aided the dissemination of Retort, in his paper "Gold mining in the Amazon: technological, environmental and social aspects" writes: "A creative solution was developed by Professor Doctor Raphael Hypolito of the University of São Paulo, a retort made of tubes and water connections. At a cost of less than $\$ 10$, this retort has been widely disseminated in Africa, the Philippines and some South American countries by the English Intermediate Technology Development Group (ITDG) (Veiga \& Silva, 2002; Veiga, 2017).

The use of Retorta RHYP has also been disclosed by the United Nations Industrial Development Organization (UNIDO) and the Blacksmith Institute and the Intermediate Technology Development Group (ITDG).

The Intermediate Technology Development Group (ITDG) has launched several campaigns, one of which is in the form of a poster in three languages: English, Spanish and Portuguese (Figure 4). 


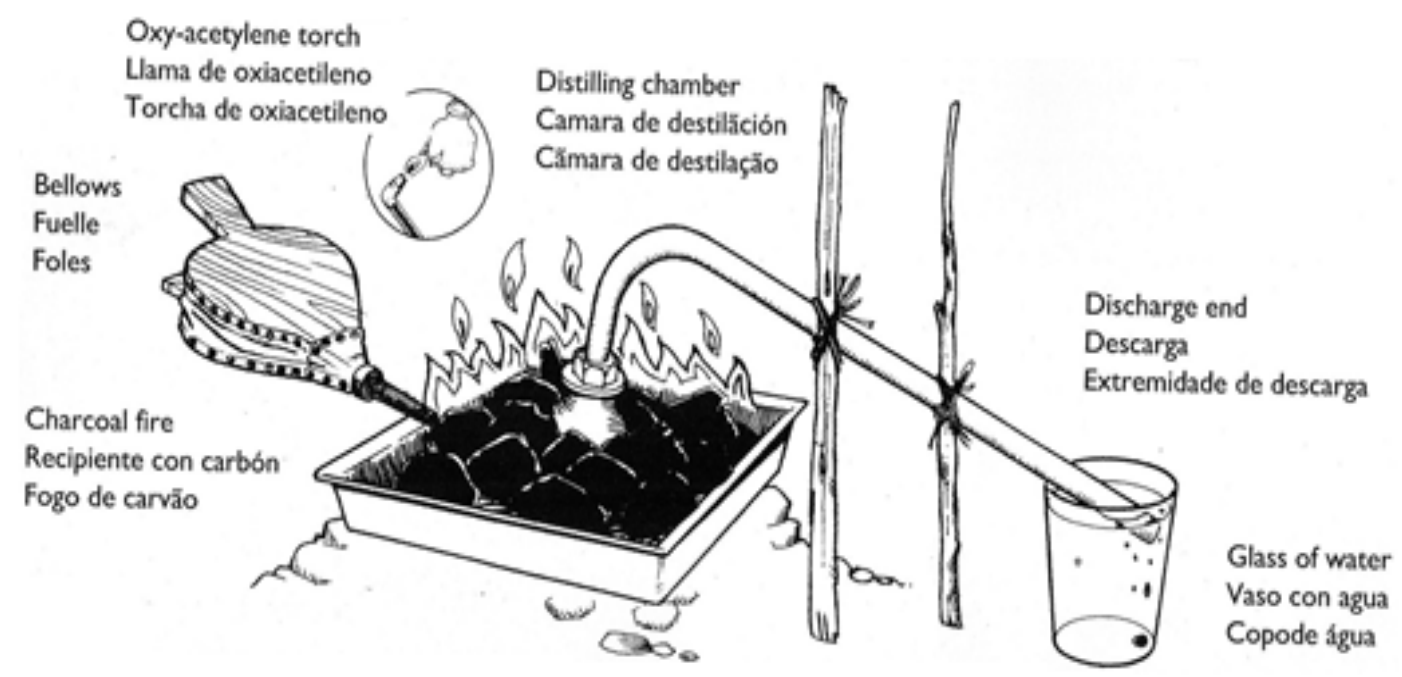

Figure 4 - Design by the Intermediate Technology Development Group (ITDG).

Although there has been intense advertising by these organizations, the main objective of this work is to aid in the dissemination of retort, which thanks to its effectiveness, low cost and facility of assembly must still be widespread. It has greatly contributed to the attenuation of Hg contamination in many gold digging regions. It has been widely used in several national gold mines (Brazil) and in foreign countries such as Tanzania, Sudan, Mozambique, Zimbabwe, the Indonesia, and some South American countries.

Next, extracted from the literature are presented pictures (Figure 5 to 8 ) of some countries where they use Retorta RHYP.
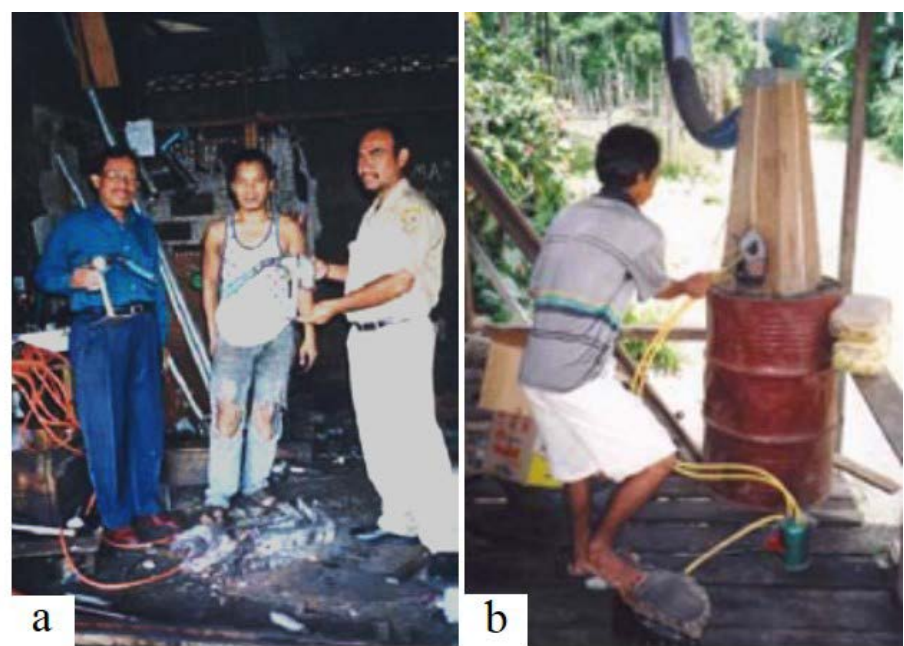

Figure 5. a) Miner in Guha, Kahayan River, Indonesia using the RHYP retort; b) amalgam burning with gasoline torch.
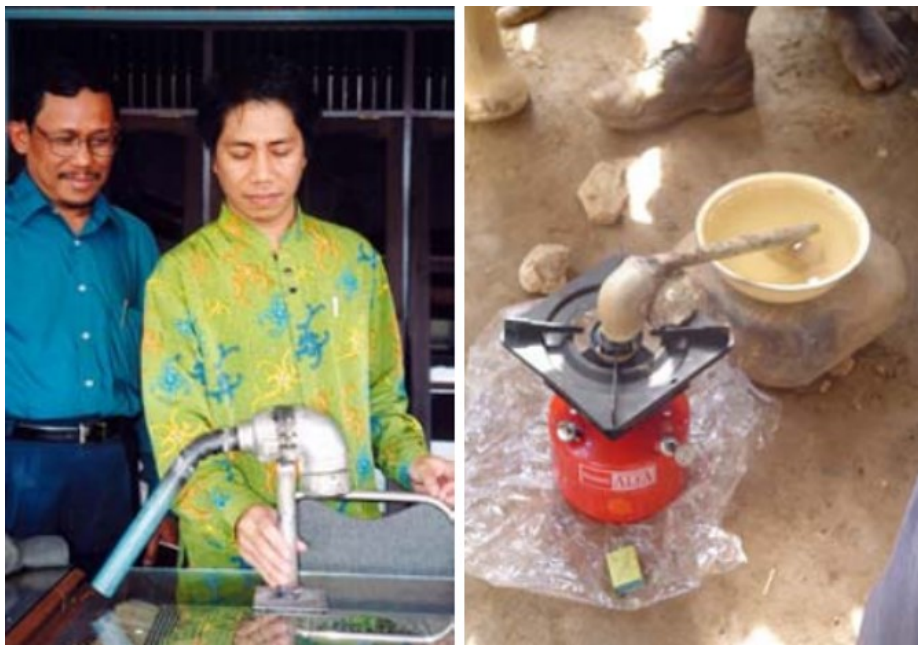

Figure 6. A prospector displaying inside the cap a gold button extracted from the amalgam in Indonesia. 

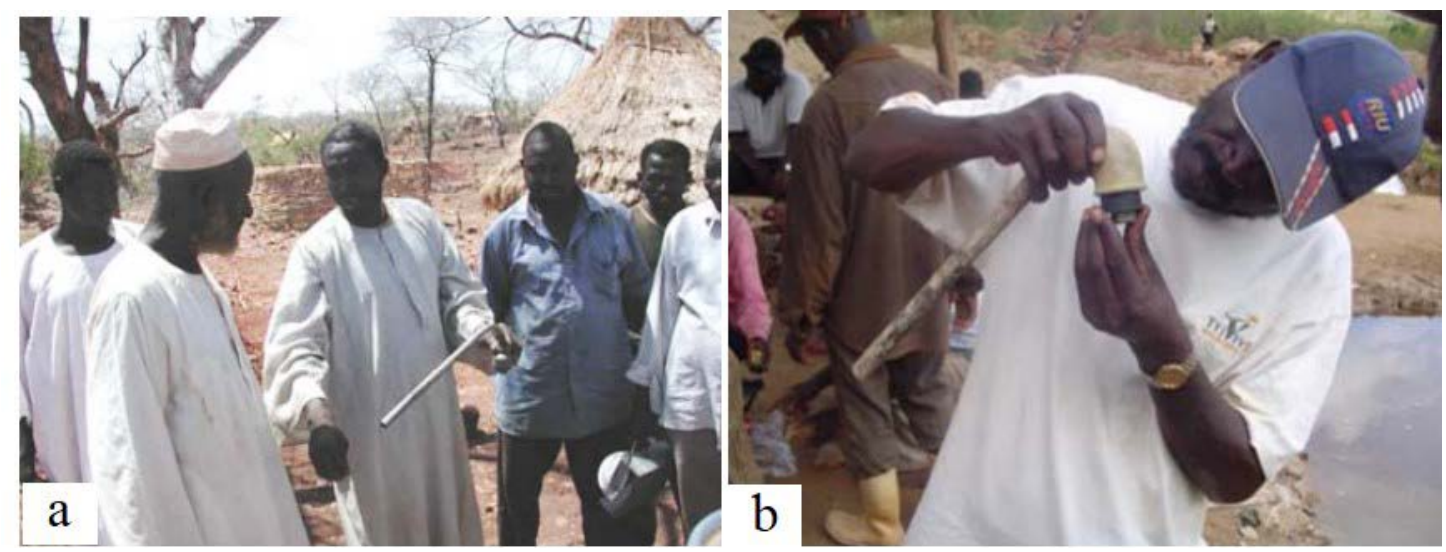

Figure 7. a) Building RHYP Retorts in Sudan and b) Munhena, Mozambique.
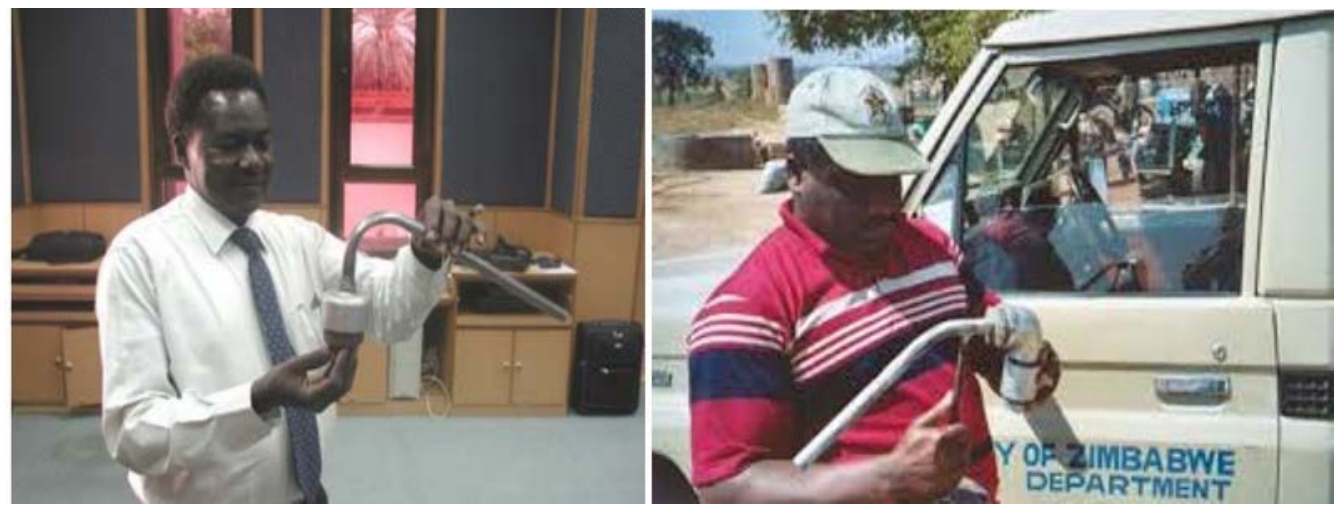

Figure 8 - Showing Retorts - RHYP in Republic of Zimbabwe.

\section{CONCLUSIONS}

The large number of experiments aimed at recovering mercury in gold amalgams, especially in digging gold, allowed the development of a versatile, easily constructed, very low cost retort (RHYP) with practically $100 \%$ yield.

Because the retort consists of few small parts and low weight, it is easy to transport, making it much easier for the gold digging miners to move in the field.

Also, it is important to stress that the use of the retort dispenses refrigeration for the condensation of the mercury.

Heating the amalgam using the retort is also greatly facilitated since it can be applied in the field in small wood fires, even in home stoves as long as the entire retort is heated leaving only the stem or condensation pipe unheated.

Finally, it is necessary to emphasize that the main objective of this work is to disclose the use of the retort, thus contributing to the reduction of mercury contamination in mining fields, which is known to be one of the major sources of mercury pollution in the environment threatening gold digging miners, the populations that live in the these areas and to all the flora and fauna of the region.

\section{REFERENCES}

ACPO: Biblioteca do mercúrio. Santos (SP): Pollution Control Association; c1994-2017 [cited 2017 july 1]. Available from: http://www.acpo.org.br/campanhas/mercurio/biblioteca_merc. html.

BAIRD, C. Química Ambiental. 2 ${ }^{\mathrm{a}}$ ed. Porto Alegre (RS): Bookman; 251 p., 2004.

BEZERRA, O.; VERÍSSIMO, A.; UHL, C. Impactos da garimpagem de ouro na Amazônia Oriental. Série Amazônia n 02, 25 p., Belém: Imazon, 1998.

HANSEN, J.C. \& DANSCHER, G. Organic Mercury: An Environmental Threat to the Health of Dietary-exposed Societes. Rev. Environ. Health, v. 12, n. 2, p. 107-116, 1997. DOI: 10.1515/REVEH.1997.12.2.107.

HYPOLITO, R. \& ANDRADE, S. Aparelho simples e barato pode reduzir poluição por mercúrio. Rio de Janeiro: Ciência
Hoje, v. 11, n. 65, p. 10-11, 1990.

HYPOLITO, R.; ANDRADE, S.; CARDENTE, R. Processo de recuperação de mercúrio em amálgama de ouro. São Paulo: Universidade de São Paulo; 1998. (Processo de recuperação de mercúrio em amálgama de ouro; $\mathrm{n}^{\circ}$. 8904036-8).

LACERDA, L,D,; PFEIFER, W,; MALM, O. Mercúrio no meio ambiente: risco potencial das áreas garimpeiras no Brasil. Acta Liminol. Brasil, v. 3, n. 2, p. 969-977, 1990.

MELAMED, R. \& VILLAS BÔAS, RC. Mecanismos de interação físico-química e mobilidade do mercúrio em solos sedimentos e rejeitos de garimpo. Rio de Janeiro: CETEM/MCT; 2002. Citação incompleta

PFEIFER, W.C.; MALM, O.; SOUZA, C.M.M.; LACERDA, L.D.; SILVEIRA, E.G.; BASTOS, W.R. Mercury in the Madeira river ecosystem, Rondônia, Brazil. Forest Ecology 
and Management, v. 38, p. 239-245,1991.

PINHEIRO, M.C.N.; NAKANISHI, J.; OIKAWA, T.; GUIMARÃES, G.; QUARESMA, M.; CARDOSO, B.; AMORAS, W.W.; HARADA, M.; MAGNO, C.; VIEIRA, J.L.F.; XAVIER, M.B.; BACELAR, D.R. Exposição humana ao metilmercúrio em comunidades ribeirinhas da Região do Tapajós, Pará, Brasil. Revista da Sociedade Brasileira de Medicina Tropical, v. 33, n. 3, p. 265-269, 2000. DOI: 10.1590/S0037-86822000000300005.

RIMOLI, L. Alerta contra o mercúrio. Revista Brasileira Tecnologia, v. 19, n. 4, p. 47-49, 1988.

STUMM, W. \& MORGAN, J.J. Aquatic Chemistry: Chemical Equilibria and Rates in Natural Waters. $3^{\mathrm{a}}$ Ed. NY Wiley; p. 1040, 1996.

TRIVELATO, G.C. Avaliação da eficácia da retorta Ourolimpo® no controle da exposição ocupacional a vapores de mercúrio na recuperação de mercúrio metálico em amálgamas e resíduos, 2009.
VEIGA, M.M. Retorts: Many options and many barriers (searching for sustainable solutions). Removal of Barriers to Introduction of Cleaner Artisanal Gold Mining and Extraction Technologies; Project EG/GLO/01/G34), 2017.

VEIGA, M.M.; SILVA, A.R.B.; HINTON, J.J. O garimpo de ouro na Amazônia: aspectos tecnológicos. In: Trindade RBE (org.) Extração de ouro: princípios, tecnologia e meio ambiente. Cap. 11. Rio de Janeiro: CETEM/MCT; p. 277 305, 2002. 